\title{
Psychological Medicine
}

VOLUME 2, 1972

BRITISH MEDICAL ASSOCIATION

TAVISTOCK SQUARE LONDON WC1H 9JR

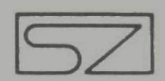

SWETS \& ZEITLINGER B.V.

LISSE - THE NETHERLANDS - 1986 


\section{Psychological Medicine}

EDITOR

MICHAEL SHEPHERD

Assistant Editors

J. L. GIBBONS K. RAWNSLEY

G. W. ASHCROFT

J. A. N. CORSELLIS

J. W. B. DOUGLAS

J. G. GIBSON

D. V. GLASS

H. GWYNNE JONES

The late G. W. HARRIS

M. LADER

SIR AUBREY LEWIS

W. A. LISHMAN

C. D. MARSDEN

W. M. MILLAR

W. D. M. PATON
The late L. S. PENROSE

CYRIL RASHBASS

GEOFFREY ROSE

G. F. M. RUSSELL

M. L. RUTTER

PETER SAINSBURY

F. KRÄUPL TAYLOR

J. TIZARD

IAN SUTHERLAND

J. K. WING

o. L. ZANGWILL

Editor British Medical Journal

Volume 2

1972

BRITISH MEDICAL ASSOCIATION TAVISTOCK SQUARE LONDON WC1H 9JR Reprinted with permission of the original publishers by

SWETS \& ZEITLINGER B.V.

LISSE - THE NETHERLANDS - 1986 


\section{Contents}

No. 1 FEBRUARY 1972

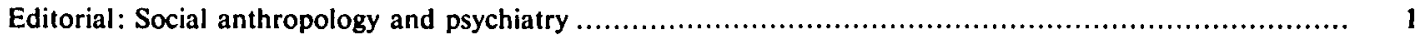

Part 2. A logical analysis of the medico-psychological concept of disease F. KRÄUPL TAYLOR................... 7

Dependence of schizophrenic patients on elderly relatives BARBARA C. STEVENS.............................. 17

Cross-national (Anglo-Irish) differences in obsessional symptoms and traits of personality M. J. KELLEHER... 33

A study of the association between quality of maternal care and infant development C. J. ROBERTS and J. R. ROWLEY....

The questionnaire measurement of psychoticism S. B. G. EYSENCK and H. J. EYSENCK.

Estimation of corticosteroids in human cerebral cortex after death by suicide, accident, or disease BENJAMIN W. L. BROOKSBANK, MARGARET A. BRAMMALL, ANN E. CUNNINGHAM, DAVID M. SHAW, ANd FRANCIS E. CAMPS

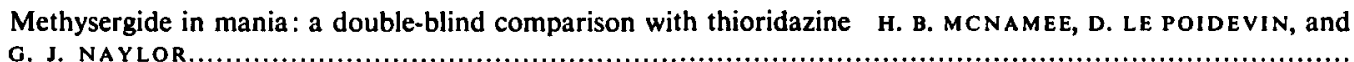
G. J. NAYLOR

Behavioural changes after treatment with testosterone: case report P. J. V. BEUMONT, J. H. J. BANCR OFT, C. J. BEARDWOOD, and G. F. M. RUSSELL.

Part 2. Improvement criteria in drug trials with neurotic patients ROBERT KELLNER

Preliminary communication: Daily variations of the urine content of 3-methoxy-4-hydroxyphenylglycol in two manic-depressive patients P. A. BOND, F. A. JENNER, and GWYNETH A. SAMPSON.

Research report: Medical Research Council Social Psychiatry Unit

Book reviews

\section{No. 2 MAY 1972}

Editorial: Pharmacology and psychiatry.....

The classification of psychotropic drugs MICHAEL SHEPHERD.

Acute effects of diphenylhydantoin in relation to plasma levels C.-M. IDESTRÖM, D. SCHALLING, U. CARLQUIST, and F. SJÖQVIST.

Selective factors in memory. Part 1: age, sex and personality attributes $\quad$ W. A. LISHMAN......................... 121

Comparative study of psychiatric patients with Klinefelter's syndrome and hypogonadism A. WAKELING....... 139

A clinical and survey study of latah in Sarawak, Malaysia $\quad$ T. L. CHIU, J. E. TONG, and K. E. SCHMIDT........... 155

The interrelationship between social class, early parent death, and mental illness JонN BIRTCHNELL........... 166

Use of hospital beds in neighbouring East London boroughs $\quad$ A. A. ROBIN and A. HAKKI.................. 176

Preliminary communication: Child guidance and delinquency in a London borough DENNIS GATH, BRIAN COOPER, and F. E. G. GATTONI.

Research report: The Addiction Research Unit of the Institute of Psychiatry, London......................... 192

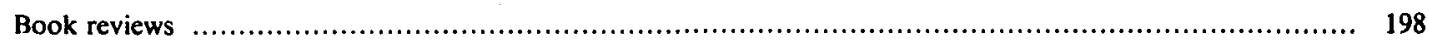

\section{No. 3 AUGUST 1972}

Editorial: Psyche and history.

Addendum: Pharmacology and psychiatry.

'Psychogenic': a word and its mutations AUBREY LEWIS. 


\section{Contents}

The occurrence of the syndrome of anorexia nervosa in male subjects P. J. V. BEUMONT, C. J. BEARDWOOD, and G. F. M. RUSSELL.

Salivation in affective disorders TOM G. BOLWIG and OLE J. RAFAELSEN ................................... 232

Chlormethiazole, sleep, and drug withdrawal J. I. EVANS, S. A. LEWIS, and M. TINKER......................... 239

Selective factors in memory. Part 2: affective disorder W. A. LISHMAN........................................ 248

Psycholinguistics of schizophrenic language GERALD SILVERMAN......................................... 254

Motivation for drinking among men: survey of a London suburb GRIFFITH EDWARDS, CELIA HENSMAN, JANE CHANDLER, and JULIAN PETO.

The Hamilton Rating Scale for depression: a factor analysis $\quad$ R. M. Mow B R A Y................................... 272

Psychiatric disorder and its declaration in contrasting areas of South Wales J. G. INGHAM, K. RAWNSLEY and D. HUGHES

An epidemiological evaluation of a public health measure aimed at reducing the availability of methylamphetamine R. de ALAR Cón

Chronic schizophrenia and discharge from hospital I. G. PRYCE

Preliminary communications:

Controlled evaluation of lithium prophylaxis in affective disorders R. L. CUNDALL, P. W. BROOKS, and L. G. MURRA Y .

Change in psychotherapy: a single case study D. A. SHAPIRO and R. F. HOBSON.

Research report: Medical Research Council Unit for the Study of Environmental Factors in Mental and Physical Illness

Book reviews

\section{No. 4 NOVEMBER}

Editorial: Neuropathology and psychiatry.

Freud and medicine in Vienna GEORGE ROSEN.

A feasibility study for a controlled trial of formal psychotherapy J. CANDY, F. H. G. BALFOUR, R. H. CAWLEY, H. P. HILDEBRAND, D. H. MALAN, I. M. MARKS, and J. WILSON

Relationship between physical and psychiatric disorder M. R. EASTWOOD and M. H. TREVELYAN.................

Changes in rating behaviour during the learning of a standardized psychiatric interview M. VON CRANACH and J. E. COOPER

Active muscular relaxation in desensitization of phobic patients S. BENJAMIN, I. M. MARKS, and J. HUSON...

Skin melanin concentrations in the affective disorders: possible relationship to the catecholamine hypothesis ASHLEY H. ROBINS

Metabolism, anticholinergic effects, and therapeutic outcome of desmethylimipramine in depressive illness D. C. WATT, J. L. CRAMMER, and A. ELKES.

Comparison of amantadine, orphenadrine, and placebo in the control of phenothiazine-induced Parkinsonism R. H. S. MINDHAM, R. GAIND, B. H. ANSTEE, and LORNA RIMMER.

Catecholamine-containing neurones and electrical self-stimulation: 1. a review of some data T. J. CROW......

Preliminary communications:

WHO International Pilot Study of Schizophrenia N. SARTORIUS, R. SH A PIRO, M. KIMURA, and K. BARRETT

Changes in glucagon level associated with anxiety or stress S. R. BLOOM, P. M. DANIEL, D. I. JOHNSTON, OLIVIA OGAWA, and O. E. PRATT

Research report: Medical Research Council Neuropsychiatry Unit, Carshalton and Epsom, Surrey. 